\title{
A User-Centric Case for Rights Reversions and Other Mitigations: The Cultural Capital Project Submission to ISED Consultation on Term Extension
}

\author{
A Brief Submitted By:
}

The Cultural Capital Project: Digital Stewardship and Sustainable Monetization for Canadian Independent Musicians

Presented to:

Innovation, Science, and Economic Development Canada

Consultation on how to implement an extended general term of copyright protection in Canada

March 09, 2021

Our submission comes from a research team that includes:

- Dr. Brian Fauteux, Assistant Professor of Music at the University of Alberta

- Brianne Selman, Scholarly Communications and Copyright Librarian at the University of Winnipeg

- Dr. Andrew deWaard, Assistant Professor of Media and Popular Culture at the University of California, San Diego

Funded by the Social Sciences and Humanities Research Council 


\section{Introduction}

The Cultural Capital Project is a SSHRC funded research project looking at remuneration for independent musicians. We are responding to the ISED Consultation paper on how to implement an extended general term of copyright protection in Canada ${ }^{1}$, as copyright legislation often purports to be in the interests of Canadian creators. Term extension is unlikely to benefit any but the largest of rightsholders, and indeed, in general independent creators typically do not benefit greatly from the promised financial exploitation promised by copyrights ${ }^{2}$. This has been made even more evident by the COVID pandemic - while copyrighted works are consumed more than ever, independent creators have sunk further into poverty. We propose mitigation strategies for term extension that would help the people who are creating Canada's cultural landscape, as well as additional actions that would alleviate additional current copyright losses.

While we appreciate the provisions given to Libraries, Archives, and Museums in the Options set out in ISED's Consultation Paper, these exceptions should be available to all creators/ users of copyrighted works (filmmakers, artists, musicians, authors, etc.), not just LAMs. Allowing LAMs to digitize materials with lower risks is great, but it does not actually put things back into the public domain - they cannot be reused by creators in the same way as public domain materials.

\section{Background: Copyright Users and Creators}

In September, 2018 we appeared before The Standing Committee on Canadian Heritage: Remuneration Models for Artists and Creative Industries on behalf of The Cultural Capital Project, a collaborative research project that investigates issues of fair payment for creators. The purpose of our appearance, and subsequent written brief, was to argue that in an industry characterized by market consolidation, an imbalance of power between creators and big businesses is one of the largest factors that prevents fair remuneration for artists. One of our key recommendations was to consider automatic rights reversions as a way to mitigate the ill effects of copyright term extensions.

Music industry representatives and lobbyists were collectively in favour of extending the copyright term. On a positive note, the "Shifting Paradigms" report that followed the consultation period did make recommendations that urge tech companies and streaming companies to support the work of Canadian creators, but there is very little in the way of tangible policy suggestions that provide an indication that these corporations will comply.

\footnotetext{
${ }^{1}$ Government of Canada, Innovation. Consultation Paper on How to Implement an Extended General Term of Copyright Protection in Canada. https://www.ic.gc.ca/eic/site/693.nsf/eng/00188.html ${ }^{2}$ Fauteux, Brian, Brianne Selman, and Andrew deWaard. "Putting Users and Small-Scale Creators First in Canadian Copyright Law and Beyond: A Brief Submitted To The Standing Committee on Canadian Heritage Remuneration Models for Artists and Creative Industries", Dec 12, 2018.

http://doi.org/10.25543/2018-12-14-5zd1-9e77
} 
Advocating on behalf of independent musicians requires a critical look at the overall infrastructure of copyright and the music industry, including Music Canada which produced the oft-cited Value Gap report. Music Canada is justified in pointing to the extractive and consolidated nature of these tech platforms and telecoms, but it fails to mention the effects of the concentration of the Canadian recording industry, perhaps because it is a trade group funded by the Canadian subsidiaries of the Big 3 record labels: Sony Music Entertainment Canada, Universal Music Canada, and Warner Music Canada. This report is not representative of the average musician's struggles and is in line with the major record labels and big businesses of the music industries that are in favour of a copyright term extension.

As noted in the Introduction to the ISED Consultation Paper, we are stakeholders who have expressed concern about term extension, both because of the lack of works entering the public domain, as well as the extension of the unavailability of out-of-commerce works. However, our brief is not on behalf of libraries, but on behalf of a particular subset of users - and creators who are crucially underrepresented in the consultation paper: independent, small-scale musicians.

\section{Recommendation 1: Include all Users, not just LAMs}

Libraries, Archives, and Museums are not the only users who are affected by the extension of copyright term. Independent creators such as artists, musicians, filmmakers, and performers are also users of copyrighted and public domain works, and the cultural realm is one of the clearest places we see the distinction between users and creators blurred ${ }^{3}$. Copyright term extension benefits large rightsholders, but likely harms independent creators and users of copyrighted materials. The impoverishment of the public domain, and the term extension of the unavailability of out-of-commerce works, affects them and their livelihoods much more directly than any slight possibility of a potential increase in royalties from term extension. Creators need mitigation approaches too, not just LAMs. De Beer and Bouchard found, for example, that 37\% of orphan work requests came from commercial enterprises (typically in the cultural industries), and a further $31 \%$ came from individuals ${ }^{4}$ - showing the vast majority of orphan works users come from outside of LAMs. These works are being used to create new cultural works (with or without new commercial viability), a process which will take longer and become more expensive with term extension. One study ${ }^{5}$ found that, "on average, just fourteen percent of sound

\footnotetext{
${ }^{3}$ Craig, Carys J., The Canadian Public Domain: What, Where, and to What End? (January 1, 2010). Canadian Journal of Law \& Technology, Vol. 7, p. 221, 2010, Available at SSRN:

https://ssrn.com/abstract $=1567711$

${ }^{4}$ de Beer, Jeremy and Bouchard, Mario, Canada's 'Orphan Works' Regime: Unlocatable Owners and the Copyright Board (2010). Oxford University Commonwealth Law Journal, Vol. 10, No. 2, p. 215, Winter 2010, Available at SSRN: https://ssrn.com/abstract=1916840

5 "One consideration by Congress in extending copyright protection to owners for such a long period was to give those owners an incentive to reissue, and thereby preserve, older recordings." TIM BROOKS, LIBRARY OF CONG., SURVEY OF REISSUES OF U.S. RECORDINGS v (2005), https://perma.cc/4ZX2-SSW8.
} 
recordings published between 1890 and 1964 had been re-released by right holders on compact disc. Non-right holders re-released twenty-two percent of those recordings without the benefit of any monopoly rights-over fifty percent more than those that did." These findings indicate that it is certainly worthwhile to consider how works in the public domain enjoy greater commercialization and dissemination than similar titles with restricted rights.

While Option 1 (expanding the orphan works regime via the Copyright Board) is not ideal in many ways, it could at least be modified to allow for commercial uses by creators. Similarly, Option 3 (permitting the use of orphan works) could be modified to include any non-commercial user, not just LAMs, as could the exceptions of Options 4 \& 5 (exceptions during the final 20 years of protection, or 100 years after creation).

\section{Mitigating Term Extensions}

In Section 2, the Consultation Paper states "Those in support have highlighted that a longer term would increase opportunities to monetize copyrighted content, and thereby increase the value of copyright holdings and encourage investment in the creation, acquisition, and commercialization of copyrighted content." It is important to note that this "highlighting" from term extension supporters is, in fact, not borne out by the evidence. Numerous studies from cultural economics, as well as the study commissioned by Heritage from Paul Heald in $2020^{6}$, have shown that term extension does not result in increased monetization of copyrighted content. Indeed, a study by economist Rachel Soloveichik estimates that over half the value of a song comes in its first three years. ${ }^{7}$ The first ten years is typically the only active period for commercial rightsholders when exploiting works. Indeed, the release of works into the public domain - the sooner the better - is what increases monetization, as new artists give a work a rebirth.

While Paul Heald calls reversion rights generally paternalistic ${ }^{8}$ (to "protect against bad deals"), we'd argue that this protection is actually a necessary balancing of the scales for a small individual against a large entity like a multi billion dollar record label. Indeed, his study commissioned for Heritage shows little downside to the rights (it does not, as is often claimed, significantly deter investment, as the investment window is much shorter than 25 years ${ }^{9}$. Yuvaraj and Giblin outline the multiple benefits of reversion rights: "the intent of minimum reversion rights should be trifold: to give authors fresh opportunities to financially benefit from

\footnotetext{
${ }^{6}$ Heald, Paul J., The Impact of Implementing a 25-Year Reversion/Termination Right in Canada (2020). Journal of Law, Technology, \& Policy, Forthcoming, University of Illinois College of Law Legal Studies Research Paper No. 20-18, Available at SSRN: https://ssrn.com/abstract=3548702 or http://dx. doi.org/10.2139/ssrn.3548702

${ }^{7}$ Soloveichik, Rachel, Music Originals as Capital Assets. https://www.bea.gov/system/files/papers/WP2013-8.pdf

${ }^{8}$ Heald, 7

9 Ibid, 26
} 
and decide the future of their works, to open new investment opportunities up to publishers and other investors, and to promote books' ongoing availability to the public ${ }^{10}$.

\title{
Recommendation 2: Rights Reversion/Termination After 25 Years
}

We are highly disappointed to see that the recommendation from INDU and Heritage to consider rights reversions is not reflected in the Consultation Paper. Rights reversions mitigate the losses to the public domain by addressing the "undesirable" state of out-of-commerce works with renewed contracts, as well as giving creators the ability to relicense works in ways that can be reused by the public if they so choose. Works that are left to languish are not necessarily commercially unviable (as discussed in Heald), they just may not be the priority for that particular rightsholder. Indeed, this is recognized in EU Directive 2019/790, sections 78-80, with Section 80 specifically addressing works which have been allowed to go out-of-commerce:

\begin{abstract}
"In such a case, and after a reasonable period of time has elapsed, authors and performers should be able to benefit from a mechanism for the revocation of rights allowing them to transfer or license their rights to another person. As exploitation of works or performances can vary depending on the sectors, specific provisions could be laid down at national level in order to take into account the specificities of the sectors, such as the audiovisual sector, or of the works or performances, in particular providing for time frames for the right of revocation."
\end{abstract}

Our recommendation is that rights would automatically revert back to authors after a period of 25 years, subject to the notification period as recommended in Heald. With rights reverting back to creators, they would have the ability to dedicate works to the public domain, engage in direct licensing, or it would enable creators to enter into a renewed or revised contract, which would be beneficial if a work was to be adapted or re-released in some way.

Rather than compulsory licenses, which increase the number and complexity of relationships with collectives (which is already overwhelming for many independent musicians), rights reversions return control to the actual creators.

\section{Recommendation 3: Out-of-Commerce Rights Reversions}

While contracts often include stipulations for what happens if the rightsholder becomes insolvent or ceases to print/exploit a work, this is not always the case, and creators (and by extension, the public) can be protected from this category of out-of-commerce by having

\footnotetext{
${ }^{10}$ Yuvaraj, Joshua and Giblin, Rebecca, Are Contracts Enough? An Empirical Study of Author Rights in Australian Publishing Agreements (November 19, 2019). Melbourne University Law Review, Vol. 44, No. 1, 2020, U of Melbourne Legal Studies Research Paper No. 871, Monash University Faculty of Law Legal Studies Research Paper No. 3541350, Available at SSRN: https://ssrn.com/abstract $=3541350$
} 
national legislation that clarifies this. For example, Yuvaraj and Giblin found that in Australian publishing contracts $13 \%$ had no out-of-commerce provision. Having national legislation ,as a number of countries already do, protects creators from unequal power relationships when negotiating contracts. "Some 50 countries have enacted legislative out-of-print rights, but in Australia, the US, the UK, Canada and New Zealand ('NZ'), they are governed entirely by contracts"11.

We recommend that there be clear reversion rights for creators whose work is out-of-commerce, so that they can either negotiate new contracts or otherwise make the works available. As Yuvaraj and Giblin note, it has become increasingly clear that objective definitions of "out-of-commerce" are required for the digital era. With services like print-on-demand or other digital provisions, it is important to clearly define "out-of-commerce". We recommend the suggestion based on royalty payments as the most clear way forward in the digital era; if a rightsholder/publisher is not paying royalties for a set number of years, the work can be effectively considered out-of-commerce for the purposes of rights reversions.

\section{Recommendation 4: Limited Liability for Non-Commercial Uses}

We appreciate the inclusion of limited liability for non-commercial use by LAMs but argue it should be extended to any non-commercial user who does due diligence and record keeping. There must be limits to statutory damages for non-commercial infringement, so that individuals aren't faced with undue fear of exercising user's rights. Any claims by rightsholders cannot be retroactive, to help prevent the abuse of this by copyright trolls.

\section{Recommendation 5: No Contract Override}

Key to creators being able to exercise these rights - and others already granted by the Copyright Act - is clarification that these rights cannot be contracted away. Record labels, publishers, and platforms should not be able to add contractual stipulations that override things like creators' moral rights, or a hypothetical reversion right. Further, an automatic rights reversion should not serve as a bargaining chip for labels or industry intermediaries to reduce other more immediate rewards for creators.

Craig \& Tarantino have documented some of the ways platforms have overridden user/creator rights during COVID, directly affecting creators' livelihoods ${ }^{12}$ (see more in the Background section that follows). When platforms are moderated by algorithm, the ability to use public domain works and compositions becomes nearly impossible. Most platforms are based in the

\footnotetext{
${ }^{11}$ Yuvaraj and Giblin, 8.

${ }^{12}$ Craig, Carys J. and Tarantino, Bob, 'An Hundred Stories in Ten Days': COVID-19 Lessons for Culture, Learning, and Copyright Law (August 5, 2020). Osgoode Hall Law Journal, Forthcoming, Osgoode Legal Studies Research Paper , Available at SSRN: https://ssrn.com/abstract=3691294 or http://dx. doi.org/10.2139/ssrn.3691294
} 
US, and do not allow Canadian exceptions. We agree with the recommendation of Craig \& Tarantino that this needs to be addressed in the "Some combination of copyright reform and consumer protection measures, for example, could seek to ensure that copyright users' rights cannot simply be overridden by boilerplate contracts (such as platform terms of service), thereby placing the onus onto online service providers to ensure that their offerings are properly solicitous of a broad fair dealing defence and other consumer concerns". ${ }^{13}$ The language used in UK copyright exceptions, "To the extent that a term of a contract purports to prevent or restrict the doing of any act which, by virtue of this section, would not infringe copyright, that term is unenforceable ${ }^{14}$, is a good starting point.

\section{Background: Independent Musicians and the Music Industry}

Our recommendations come out of an understanding of independent musicians as creators in the Canadian copyright context. Our use of "independent" to define artists is to point to those artists who are not amongst the most successful and financially stable across the music industries and who may engage in music making that operates at some distance from the major record industry. These musicians - indeed, the vast majority of musicians whose work does not make it into the top $1 \%$ of sales - have different interests than those represented by the music industry lobbyists. Their relationship to copyrights are quite different than those artists affiliated with major record labels. Most of them make a small \% of their income from directly copyright-related activities, and many have mixed incomes, meaning they do not get their income solely from music. Much artist revenue has to be sustained by aggressive touring, an option only open to a few and one that is difficult given Canada's vast geographical area - and impossible in a pandemic. In our research on independent music artists in Canada we have found that a number of barriers exist to achieving a sustainable livelihood in the contemporary music industries, many of which have been compounded by the global COVID pandemic.

As part of our research, we recently interviewed 18 musicians in Edmonton and Winnipeg. While some artists have recognized the need to understand copyright and their own options with respect to their rights, this knowledge is not widely accessible and an issue of transparency and power imbalances in contract negotiations remains. One artist we interviewed mentioned that one record label was "reluctant to even tell us what the records had sold" and that there was very little sense of what money was coming in from streaming music services. Another cited the importance of transparency when dealing with contracts but that it is expensive to hire an entertainment lawyer. This artist added that "for the next album that I'm putting out, I made the decision to hold on to my masters...it's a huge income stream if you do get your songs played on the radio or satellite radio." Independent musicians have a sense of the structural asymmetry

\footnotetext{
${ }^{13} \mathrm{lbid}, 602$.

${ }^{14}$ https://www.legislation.gov.uk/uksi/2014/1372/regulation/3/made The Copyright and Rights in Performances (Research, Education, Libraries and Archives) Regulations 2014. https://www.legislation.gov.uk/uksi/2014/1372/regulation/3/made
} 
within contracts and negotiating their copyrights; assessing the wider infrastructure of the music industry shows how unequal the playing field has become.

This unequal playing field has partially come about because of how effectively copyright as an exclusive right has been leveraged by corporate oligopolies when it comes to building up and concentrating assets, which is a significant barrier to new and innovative players in the cultural industries. Canada's music industry is controlled by a tight group of mainly American transnational music, technology, and financial companies. In recording and publishing, the "Big Three" of Universal Music Group, Sony Music Group, and Warner Music Group dominate the industry. Furthermore, as noted in the copyright review, streaming music has worsened the treatment of independent musicians. Digital service providers (such as Spotify, Apple, and Amazon) have altered the established method by which songwriters and recording artists are paid. Rather than discrete record sales, a DSP uses subscription and ad-based pricing, which has depressed the royalty rates paid to musicians, now "too low to fully sustain a full-time career as a recording artist for the majority"15.

Canada has one of the highest rates of major label market share in the world, at $75 \%{ }^{16}$ Only Spain, Denmark, and the UK had a higher rate. Correspondingly, Canada has one of the lowest rates of independent record label market share at 25\%. Even the United States has higher (38\%). The global average is $40 \%$, while more equitable countries like Japan (63\%) and South Korea (83\%) should be the goal. It is no wonder that Music Canada's solution to the "value gap" is punitive copyright legislation; the Big 3 record labels would continue to profit handsomely within their oligopoly. As a large amount of new research indicates, antitrust reform and tax increases are increasingly necessary to tame the power of monopoly in the new gilded age.

The result of this consolidation, homogenization, and financialization in the music industries has been a boon for corporations and superstar musicians, but devastating for average musicians. The statistics are shocking:

- A recent Citigroup report found that the U.S. music industry generated $\$ 43$ billion USD in 2017 , but artists received only $12 \%{ }^{17}$

\footnotetext{
${ }^{15}$ Towse, Ruth. Dealing with Digital: The Economic Organisation of Streamed Music (June 2020). Media, Culture \& Society, Vol. 42, Issue 7-8, pgs 1461-1478. doi: 10.1177/0163443720919376.

${ }^{16}$ According to the WINTEL Worldwide Independent Market Report in 2018. https://winformusic.org/files/WINTEL\%202018/WINTEL\%202018.pdf

${ }_{17}^{17}$ Sanchez, Daniel. The Music Industry Generated \$43 Billion in Sales Last Year. Artists Only Received $12 \%$ of That (August 7, 2018). Digital Music News.

https://www. digitalmusicnews.com/2018/08/07/citigroup-music-industry-sales/
} 
- The top $1 \%$ of artists accounted for $77 \%$ of all recorded music income in $2014 .{ }^{18}$ By 2020 , the top $1 \%$ was accounting for $90 \%$ of streams and the top $10 \%$ of artists accounted for $99.4 \% .^{19}$

- The 10 top-selling tracks command $82 \%$ more of the market and are played almost twice as much on Top 40 radio than they were a decade ago. ${ }^{20}$

- The average American musician made only $\$ 21,300$ from their craft in 2018 and $61 \%$ report music income is not sufficient to meet their living expenses (MIRA Survey of Musicians). ${ }^{21}$

- In Canada, the average musician only makes $\$ 17,900 /$ year, less than half of the average Canadian worker's income, and well below the poverty line. ${ }^{22}$

It is more winner-take-all in the music industries than ever before and the vast majority of creators are struggling to earn a living.

Issues of diversity and inclusion are another concern when considering worsening inequality within the streaming age of music. Amidst this corporate consolidation, listener data are showing a reduction in the diversity of music across vectors of gender, class, and ethnicity.

- All of Spotify's most-streamed artists in 2018 were men. ${ }^{23}$

- Billboard's Hot 100 songs from 2012 to 2017 had an average of $16.8 \%$ female performers, $12.3 \%$ female songwriters, and only $2.1 \%$ female producers. ${ }^{24}$

- Only $12 \%$ of musicians in the UK in 2019 were from a working class background, down from $20 \%$ in previous years; women and people of color were further disadvantaged. ${ }^{25}$

- In Canada, female artists make 82 cents of total income for every dollar of male artists, with Indigenous artists making only 68 cents on the dollar. ${ }^{26}$

\footnotetext{
${ }^{18}$ Mulligan, Mark. The Death of the Long Tail: The Superstar Music Economy (March 2014). MIDiA Consulting. https://musicindustryblog.wordpress.com/2014/03/04/the-death-of-the-long-tail/

${ }^{19}$ Smith, Dylan. 1\% of Artists Generate $90 \%$ of All Music Streams, Latest Data Shows (September 10, 2020). Digital Music News. https://www.digitalmusicnews.com/2020/09/10/music-streams-data

${ }^{20}$ Thompson, Derek. The Shazam Effect (December 2014). The Atlantic.

https://www.theatlantic.com/magazine/archive/2014/12/the-shazam-effect/382237

${ }^{21}$ Krueger, Alan B. and Ying Zhen. MIRA Survey of Musicians (June 19, 2018). Music Industry Research Association. https://psrc.princeton.edu/news/mira-survey-musicians-april-june-2018

22 Hill, Kelly. A Statistical Profile of Artists in Canada in 2016 (November 27, 2019). Hill Strategies

Research. https://hillstrategies.com/resource/statistical-profile-of-artists-in-canada-in-2016/

${ }^{23}$ Byager, Laura. Spotify Just Released this Year's Most-Streamed Artists and They're All Male

(December 4, 2018). Mashable. https://mashable.com/article/spotify-most-streamed-artists-male/

${ }^{24}$ Smith, Stacy, Marc Choueiti, and Katherine Pieper. Inclusion in the Recording Studio? Gender and Race/Ethnicity of Artists, Songwriters \& Producers across 600 Popular Songs from 2012-2017 (January, 2018). Annenberg Inclusion Initiative. https://annenberg.usc.edu/research/aii.

${ }_{25}$ Carey, Heather, Rebecca Florisson, Dave O. Brien, and Neil Lee. Getting In and Getting On: Class, Participation and Job Quality in the UK Creative Industries (August 27, 2020). Creative Industries Policy \& Evidence Centre.

https://pec.ac.uk/research-reports/getting-in-and-getting-on-class-participation-and-job-quality-in-the-ukscreative-industries

${ }^{26}$ Hill, Kelly. Demographic Diversity of Artists in Canada in 2016 (January 29, 2020). Hill Strategies

Research. https://hillstrategies.com/resource/demographic-diversity-of-artists-in-canada-in-2016/
} 
One further issue heightened by market consolidation is the collection and monopolization of user/listener data. Platforms are increasingly able to collect and monetize citizens' private usage data, usually in a way that is not transparent to listeners themselves. Listening data has value, similar to the data and knowledge generated by academic research and in cases where public funds have gone into programs/projects, this data should have the same requirements of openness as research data. In both the Heritage and INDU committees, the lack of market data to inform decisions is evident.

\section{Background: Canadian Musicians and COVID}

What we see clearly from the impacts of COVID is that, for the vast majority of Canadian independent musicians, copyright related economic activity is not a significant enough proportion of income to keep them afloat when touring and live shows are on hold. Canadian musicians have plunged into an even more precarious situation and faced job losses, the cancellation of potentially profitable tours, and, as a result, may be unable to meet their basic needs.

Early in the pandemic, 39\% of respondents to a Canada Council for the Arts survey were concerned that the outlined emergency measures - CERB, CEWS, CEBA - would not be sufficient for themselves or their arts organization ${ }^{27}$. Many of the individuals surveyed by Canada Council would not be applying for CERB as they had some income and did not qualify. Confusion about eligibility also led many to not apply ${ }^{28}$, fears which may have been well placed after requests to pay back CERB money were released. While we appreciate the retroactive clarification for income earners under $\$ 5,000$, which many arts organizations lobbied for, many independent musicians with mixed incomes have fallen through the cracks of income support.

Abacus Data (funded by Music Canada, an industry lobby representing the large record labels listed above) found ${ }^{29}$ that:

- $85 \%$ of musicians surveyed rely on performing to earn a livelihood as a musician

- For the second half of 2020 , the average number of bookings for musicians was eight, down from 2019's average of 87

- More than half of the musicians surveyed in June of 2020 had zero performances booked for the remainder of the year

\footnotetext{
27"Input on Measures to Offset Impacts of COVID-19 on Arts Sector." Canada Council for the Arts, https://canadacouncil.ca/research/april-2020-covid19-client-survey

${ }^{28}$ Freelance Artists Await More Information on How Online Art-Making and Royalties May Affect

Emergency Benefit Eligibility. The Globe and Mail,

https://www.theglobeandmail.com/arts/theatre-and-performance/article-freelance-artists-await-more-infor mation-on-how-online-art-making-and/

${ }^{29}$ Abacus Data, Crowded Out: What Canada's Professional Musicians Say the Impact of the Pandemic Has Been on Their Lives, Art, and, Work. https://abacusdata.ca/crowded-out-musicians-live-performances-covid19-pandemicl.
} 
- $78 \%$ of musicians surveyed said anxiety from the pandemic had negatively affected their ability to create.

As there is not much Canadian pandemic-related data on the work of musicians, sources from the United States may be necessary to start to understand the impact on individual independent musicians. A survey from the Music Worker Alliance in the US found ${ }^{30}$ :

- $71 \%$ of musicians and DJs surveyed have lost more than $75 \%$ of their income during the pandemic

- Between the 213 survey respondents, more than $\$ 8.5 \mathrm{M}$ USD was estimated as lost income

- Unemployment insurance rarely covered the full loss of income for musicians, as many are mixed income workers

- Only a small minority of musicians and DJs are working during the pandemic, and it is often for free or for less than they would have before the pandemic.

Live performances - not copyright related activity - are what keep many independent musicians in Canada afloat, so outside of the effects of term extension, what role does copyright legislation play for them?

\section{Copyright Losses}

Practices and legislation in the realm of copyright has not helped independent creators during COVID. Indeed, as Craig \& Tarantino have outlined, many platforms have increasingly relied on technology and algorithms rather than humans to enforce (their interpretation of) copyright during the pandemic, leading to interruptions and takedowns of performances, DJs doing remixes, livestreams of public domain music being cut off, and spurious takedowns of user-generated-content. "Studies have indicated that up to 30 percent of automated takedown requests are problematic in the sense that there were issues with the accuracy of the "matching" between the library of protected content and the new content ${ }^{31}$; and even more concerning, most of these algorithms do not take Canadian legislation - such as the non-commercial "You Tube" exception or incidental inclusion. The unfair and preemptive interruption of creator's performances goes against the principles of notice-and-notice (designed to protect against false claims), and can significantly affect their only avenues for payment.

\footnotetext{
${ }^{30}$ MWA, How Are We Surviving: Survey Summary Report, Google Docs, https://drive.google.com/file/d/1mAMv2N6xQ-oPCE4gpsd4_658L8_PPTkZ

${ }^{31}$ Craig \& Tarantino, 578.
} 